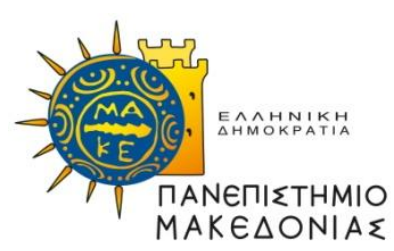

ПРАЕН:

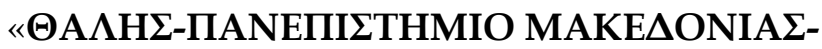

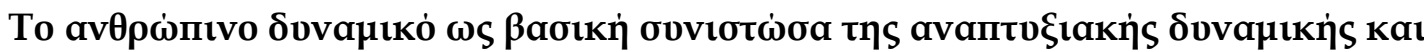

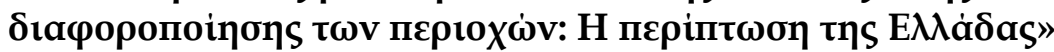

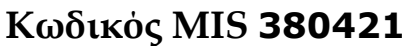

\section{ҮПОЕРГО:}

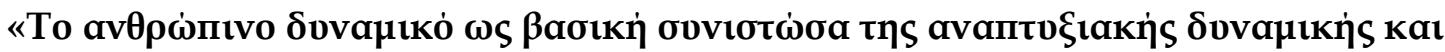

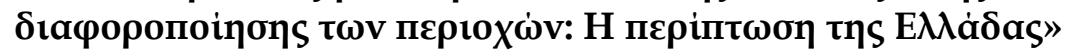
Kal a/a «01»

\section{ЕПІХЕІРН $\Sigma$ IAКО ПРОГРАММА:}

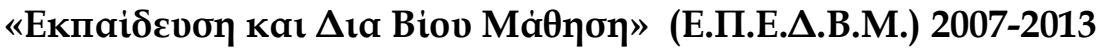

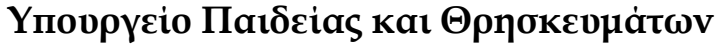

A $\Xi O N A \Sigma$ ПPOTEPAIOTHTA $\Sigma 11:$

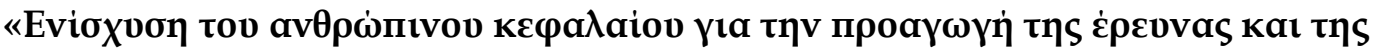

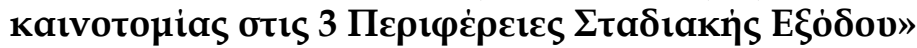

\section{КАТНГОРІА ПРАЕН $\Sigma$ :

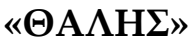

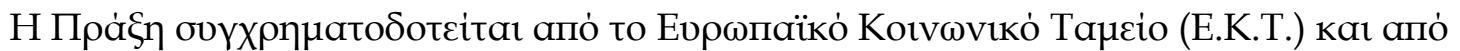

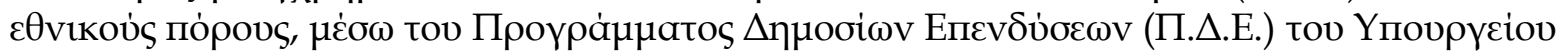

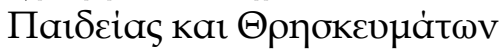

\section{Паработѐं}

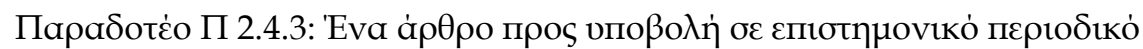

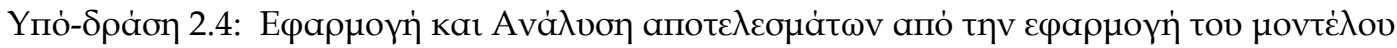

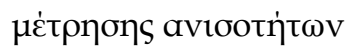

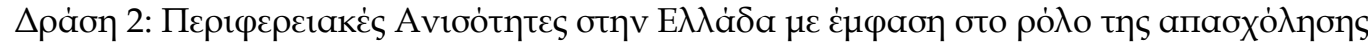

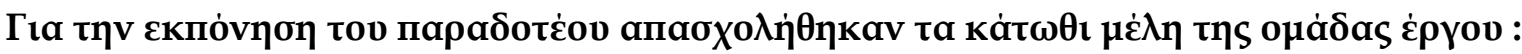

MEAH KYPIA $\Sigma$ EPEYNHTIKH $\Sigma$ OMA $\triangle A \Sigma($ K.E.O.)

\YMПЕРАKH ANTIГONH 


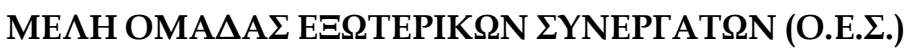

ПANTAZH $\Sigma$ ПANAГI $\Omega T H \Sigma$

ГIAPOY K $\Omega N \Sigma T$ TANTINA

AӨn்va, 30/11/2015 


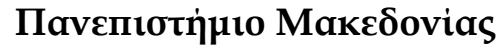

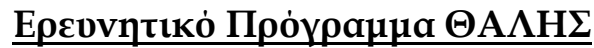

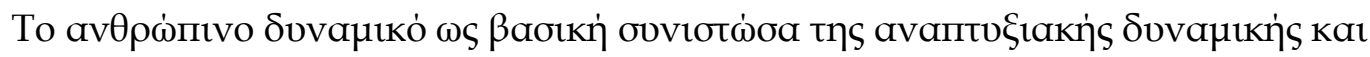

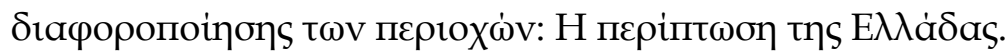

OMA $\triangle A$ EPГA $\Sigma I A \Sigma 2$

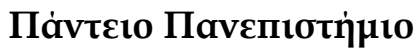

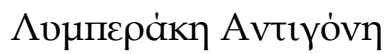

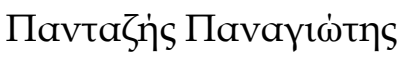

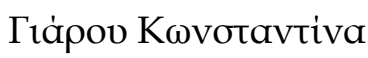




\title{
Regional economic development, human capital and transport infrastructure in Greece: the role of geography
}

by Vassilis Tselios, Antonis Rovolis \& Yannis Psycharis

\begin{abstract}
This chapter discusses the impact of human capital endowment and transport infrastructure on regional economic development and growth in Greece, with a special focus on the role of geography. The relationship between regional development, human capital and transport infrastructure is far less direct and is, indeed, complex. Geography plays an important role in the functioning and performance of regional economies in general and the Greek economy in particular. Both first nature of geography factors (i.e. physical geography of regions) and second nature of geography factors (i.e. geography of distance between economic agents) moderate this relationship. This chapter also draws out a number of implications with regard to the role of regional economic policy.
\end{abstract}

Acknowledgements: This chapter is based on research that has been co-financed by the European Union (European Social Fund) and Greek national funds through the Operational Program "Education and Lifelong Learning" of the National Strategic Reference Framework - Research Funding Program: THALES. Investing in knowledge society through the European Social Fund (grant number MIS 380421). We also thank Panagiotis Pantazis (MSc in Planning and Regional Development, PhD student) for the construction of the Figures. 


\section{Introduction}

This chapter attempts to synthesise the various causal mechanisms that have been proposed in the literature to explain the relationship between regional development, human capital and transport investments in Greece, by increasing our understanding of the role that geography plays in the functioning and performance of regions. It will allow us to understand why economic activities tend to concentrate in specific Greek areas. The ultimate aim of the chapter is to draw some kind of potentially useful inference for regional policy makers whose primary concern is to guarantee both equity and efficiency.

Despite the abundance of the theoretical and empirical literature dealing with the regional development, human capital and transport infrastructures nexus, we think that, specifically for the Greek economy, the reverse causality of this nexus has not been explored enough. Hence, this study not only sheds light on this relationship, but also contributes to the empirical analysis by providing descriptive analysis and mapping regarding the Greek case.

The remainder of the chapter is organised as follows. In Section 2, we debate regional economic development in Greece. In Section 3, we discuss the theoretical underpinnings of the human capital and economic development relationship and in Section 4 those of the transport investment and economic development relationship. In Section 5, we discuss whether we need additional drivers for the understanding of the association between regional development, human capital and transport infrastructure, examining the role of the first and second nature of geography. In Section 6, we draw out a number of policy implications with regard to the role of regional economic policy, and more specifically to the economic efficiency and equity issues. In Section 7, we conclude.

\section{Regional economic development in Greece}

Regional economic development is the application of economic processes and resources available to a region (Stimson, Stough, and Roberts 2006). The term 'region' is a geographical sub-unit of the national economy and is used to refer to administrative areas and political jurisdictions (Armstrong and Taylor 2000). The standard measure of the performance of a regional economy is Gross Domestic Product (GDP) per capita designed to 
measure the total output per capita in a particular region, including services (European Commission 1999). More specifically, GDP includes the total output of goods and services for final use produced by a regional economy, by both residents and non-residents, regardless of the allocation to domestic and foreign claims. GDP is a measure of aggregate income on a macro level, through it excludes transfers of income from individuals, companies and government in the form, for example, of social benefits (European Commission 1999). A region that has a low level of production might have a relatively high level of income due to large social security transfers, but it would still be a less favoured region (European Commission 2004: 25-26).

However, there are certain problems encountered in the use of GDP per capita as a measure of economic development, especially for city-regions. City-regions, such as the region of Attiki, are underbounded regions, which are smaller than their Functional Urban Regions (FURs) (Cheshire and Hay 1988). The administrative definition of cities in Europe bears no constant relation to any functional definition (Cheshire and Hay 1988). The administrative definition of cities does not capture the economic sphere of influence of a city. Conversely, 'FURs are functional in that their boundaries are determined on the basis of economic relationships rather than history or political divisions' (Cheshire and Hay 1988: 15). The bigger the city, the smaller the spatial units chosen, the greater the measurement bias is likely to be. For instance, the municipality of Athens is considerably smaller than the FUR of Athens. The fact that central cities are likely to provide public services that benefit populations living in the rest of the metropolitan area but working, studying or shopping in the central city (Greene, Neenan, and Scott 1974) is not observable in large city-regions. The interdependencies between central cities and their suburbs are not captured. In city-regions, commuting by people resident in other regions adds to the local workforce and GDP. The city-region's GDP per capita as a measure of income per capita is, therefore, overstated, while that of neighbouring regions is understated (European Commission 1999). Additional problems encountered in the use of GDP per capita as a measure of economic development within regions are that GDP counts work that does not produce a net change or that results from repairing harm, such as a natural disaster (e.g. an earthquake); cross-border trade within companies (e.g. to escape high taxation) distorts the GDP; and if a region does not spend, but saves and invests in other regions, its GDP will decline in comparison to a region 
that spends borrowed money. Finally, GDP does not include deductions for depreciation of physical capital or depletion and degradation of natural resources. ${ }^{1}$ These features of GDP are very pronounced in the case of Athens which extends its activities beyond its regional boundaries (Petrakos and Psycharis 2015a).

[Insert: Figure 1]

Figure 1 presents regional (i.e. prefectural NUTS III) GDP per capital in Greece for the year 2002. This Figure shows that there are important asymmetries in the distribution of production and wealth across the Greek territory. Some of these observations stand out. First, the Greek economic space is dominated by the presence of the metropolitan area of Athens, which is included in the Attica Region, but functionally extends beyond that, embracing clusters of significant industrial activity located in a short distance beyond its borders in the neighboring regions (Petrakos and Psycharis 2015b). Even without its 'satellites', the Attica region accounts for $36 \%$ of the national population and $50 \%$ of national GDP in 2012, maintaining a regional GDP per capita that is the highest in the country and $32 \%$ above the national average. Furthermore, Voiotia, the adjacent to Attiki region, where it has been 'exposed' a large part of the industrial activity of Attiki, is the only continental region, with GDP per capita above the country average (by 15\%). Looking at the map of the country the more relatively well-off areas are these on the ' $\mathrm{S}$ ' axis, that starts from Thessaloniki, along the eastern coast of continental Greece until Athens and continues to the Northern cost of Peloponnese until Patras. Finally, it is evident that the majority of islands enjoy a higher GDP per capital relative to the country average with the Cyclades holding the second position in the ranking.

\section{Regional economic development and human capital in Greece}

A major force shaping economic development is human capital, which is considered a multidimensional concept. It has been defined by the Centre for Educational Research and Innovation and Organisation for Economic Co-operation and Development (1998: 9) as 'the knowledge, skills, competences and other attributes embodied in individuals that are

\footnotetext{
${ }^{1}$ www.undp.org/hdr2001/ — United Nations Development Programme.
} 
relevant to economic activity'. A number of economists have adopted the broad concept of human capital, including the work of Adam Smith in the eighteenth century. The pioneering work of Schultz $(1961,1962,1963)$ views human beings as types of capital and investment. He treats human resources as a form of capital. People who invest themselves extend the range of choice that is available to them, enhance their welfare and, subsequently, the economic development of their society.

Schultz (1961) has classified human activities using five major dimensions. The first dimension is that of formally organised education at the elementary, secondary and tertiary levels. The cost of this type of human capital consists of the costs of the services of teachers, librarians and administrators. It also includes the costs of maintaining and operating the educational plant and the income foregone by students. The second dimension is the onthe-job training organised by firms. It differs from formal education in that investment is made within the workplace rather than in an institution that specialises in teaching (Becker 1962). The cost of this training is usually borne by employers and depends on the type of training and on the demand for different skills. The aim of such training programmes is to adjust the education of workers to the demand for new skills and abilities. Training is regarded as an important aspect of labour market flexibility. A lack of mobility, for instance, may inhibit the scope for firms to bring about changes in work practice and organisational structures (De Serres 2003; OECD 2003). The third dimension is the study programmes for adults that are not organised by firms, such as the extension programmes in agriculture that contribute to transmitting new knowledge and to developing skills among farmers. The fourth dimension is the migration of individuals and families to adjust to changing job opportunities. The movement of people from one sector to another changes their overall welfare. The fifth dimension of human capital is that of health facilities and services which includes all expenditures that affect life expectancy, strength and stamina, and the vitality of people, among others.

Economists, sociologists and geographers have extended the concept of human capital to many other areas. According to Becker (1962), an additional dimension of human capital concerns the acquisition of information about the economic system. Generally speaking, the economic system influences the efficiency, allocation and distribution of human resources. 
People can reduce the risk of their investment if they have a better knowledge of the market. Spence (1973) supports the notion that education may act as a 'signal' because of imperfect information which may generate temporary educational mismatch. For instance, the coexistence of a high incidence of overeducation among school-leavers and a lack of work experience reflects the educational mismatch (Hartog 2000). This type of mismatch conceptually differs from the skill mismatch that is the actual mismatch between acquired and required skills (Allen and van der Velden 2001). Hence, the acquisition of information about the economic system influences not only the distribution of human beings, but also the educational and skill mismatch. Benporath (1980) places emphasis on another dimension of human capital, the 'personal' or 'specific' human capital created by investments in reputation and personal relationships, which is known as the F-connection (i.e. families, friends and firms). Similarly, Becker (1962), Becker and Tomes (1986) and Becker and Barro (1988) have extended human capital to encompass marriage, fertility and family relations. Closely related to 'specific' human capital is the concept of social capital (Bourdieu 1993; Coleman 1988; Putnam 1993). However, social capital is generally understood to be a matter of relationships rather than the property of individuals (Schuller 2000). Thus, human capital focuses on the economic behaviour of individuals, while social capital on networks, norms and trust.

Educational attainment is the most used proxy for human capital as it can be defined in terms of various human attributes, such as the knowledge, skills and competences embodied in individuals that are relevant to economic activity. It is usually measured as the percentage of the population who have successfully completed various 'levels' of formal education. The term 'level' is defined in relation to the years of study and the age associated with an educational cycle. These indicators show how many people have completed each level of initial education. A related measure is the average number of years of schooling completed. It assumes that a year of education will add a constant quantity to the human capital stock, whether undertaken by a primary school child or a post-graduate student. However, these measurements do not take into account the quality of educational attainment. The ideal measures of human capital would be in terms of the output of education, but due to the difficulties of obtaining such measures, input measures tend to be used instead (Sianesi and Van Reenen 2003). Completion of educational levels is only 
broadly associated with certain forms of economically-relevant knowledge, skills and competence and does not look at the human capital stock attributed directly. Hence, such measures of regional differences in educational attainment cannot explain differences in adult literacy performance. In other words, they do not measure how much in practice such attributes are worth in economic terms. It should be noted here that neither proxy takes into account the fact that skills are lost through disuse. They ignore the depreciation of human capital which is often associated with unemployment and economic inactivity. A person's qualifications are kept for life, while the qualities required to gain them may depreciate over time (Centre for Educational Research and Innovation and Organisation for Economic Co-operation and Development 1998). To sum up, the proxies analysed are more measurements of the quantity and availability of a region's human resources (input measures), rather than measurements of the quality of human capital endowments (output measures). In measuring the quantity of education, one only gains a crude idea of skill differences (Hanushek and Kimko 2000).

[Insert: Figure 2]

Figure 2 portraits the University graduates holding a postgraduate diploma at NUTS III regions in Greece and shows that there are important differences in the level of education of people among regions. This figure shows that inequalities in concentration of the most educated human capital follow a similar pattern to the regional economic development and they are concentrated in the most urbanized areas of the country. In addition, these regions are the location of the largest Universities and educational institutions in the country. Attiki, which stands out as the most developed and the most urbanized area of the country, is the region with the highest percentage of graduates. Conversely, mountainous, remote and boarder regions which are lacking behind in terms of economic development also suffer from deprivation of educationally upgraded human capital. The correlation between economic wealth and educational level seem to be very high. This is further supported by all the educational indices. According to the Greek Population Censuses data $49 \%$ of the population that has completed tertiary education and $64 \%$ of the population holding a postgraduate degree are concentrated in Athens Metropolitan Area (Petrakos and Psycharis 2015a). Thessaloniki, which is the second NUTS III region in this ranking, is hosting the $11 \%$ 
and $13 \%$ respectively. Together, these two regions host the $60 \%$ of people holding a University degree and the $77 \%$ of them holding post-graduate degree (Petrakos and Psycharis 2015a).

\section{Regional economic development and transport infrastructure in Greece}

The relationship between regional economic development and transport infrastructure is a highly complex issue involving aspects of public-good provision, the generation of externalities and political decision-making (McCann and Shefer 2004). Most studies have accepted the position that transport infrastructures contribute positively to economic development. The pioneering studies of Aschauer (e.g. Aschauer 1989) concluded that public capital (including transport infrastructures) was a factor of enormous importance in explaining the evolution of economic performance in the United States. Later studies (e.g. Duffydeno and Eberts 1991) provided additional evidence for the results obtained by Aschauer.

The theoretical background on the positive relationship between transport infrastructures and economic development is multifarious. First, the net benefits associated with the public transport infrastructure are related to increases in the net local income, which stem from either private investments due to the reductions in transport costs and travel times or positive externalities as the income of the non-users of the infrastructure may increase due to increases in local demand on the part of the infrastructure users (McCann and Shefer 2004). Second, investments in transportation change the relative accessibility of a region. An increase in the level of connectivity implies a greater ability on the part of local firms to develop profitable market relationships with firms and consumers either within or between regions. In other words, a high quality transport infrastructure creates opportunities for interaction among firms and customers and for all economic agents. Firms that are located in areas with a better infrastructure will be more integrated into the market system and more exposed to competition and, thus, under more pressure to improve productivity (Deichmann et al. 2004). Greater choice, innovation and intellectual opportunities for agents imply the development of inter-regional and intra-regional linkages, and thus higher economic development (Vickerman 1991). When the road and rail infrastructure, for example, improves the relative accessibility of a region, it can provide for an increased rate 
of return on investments relative to other competing locations (McCann and Shefer 2004). Additional mobile resources (either capital or labour) from outside the region may be attracted to the area with the new infrastructure. This immigration of factors contributes to regional economic development. Based on this evidence, where transport infrastructure facilities are developed, it is easier for entrepreneurs to adopt new technologies and, consequently, this generates technical progress and regional economic development (Demurger 2001). Third, poor resource endowments may lead to limited access to educational and socioeconomic opportunities. Transport infrastructures offset some of the inherent disadvantages of lagging regions, because they connect remote regions to urban areas (Henderson, Shalizi, and Venables 2001). Fourth, transport infrastructures reinforce the cumulative causation process. Firms produce more efficiently and workers enjoy higher levels of welfare by being linked to large markets through a good transport infrastructure network. The large markets are, in turn, those where more firms and workers are located. Fifth, a good infrastructure network across regions might imply efficiency in the transportation of inputs (labour and capital) as well as potential increases in their price, and thus a higher growth rate. Transport facilities for both passengers and freight are usually critical to the competitiveness and prosperity of a region (European Commission 1999). Without a good infrastructure network, problems of both inefficiency and competitiveness may impede economic development (Demurger 2001). Therefore, infrastructure can contribute to economic development, either directly as a measurable final product, or indirectly as an intermediate input, because infrastructure enhances the productivity of all other inputs in producing output (Wang 2002) and it generates positive externalities. In other words, the first impact comes from the construction expenditure, while the second comes from the costs and revenues associated with its operation (Puga 2002).

However, some studies seem to contradict the widely accepted hypothesis that investment in the transport infrastructure always favours economic development and growth (HoltzEakin 1994; Holtz-Eakin and Lovely 1996). While a transport infrastructure may encourage development in under-developed regions, its construction alone will not be enough to bring about any desired economic changes (McCann and Shefer 2004). Other factors, such as the resource endowments of the region, the economic climate in the region, the prices of the input factors of production, government policies and underlying infrastructure tend to 
determine the economic viability of a region, far more than its transport infrastructures (McCann and Shefer 2004; Vickerman 1991). Complementary actions and policies need to be taken to ensure that lagging regions are in a position to profit from the opportunities created by improvements in road and rail transport (European Commission 1999). The benefits of a good transport infrastructure are not necessarily unlimited. If infrastructure investments increase the rate of growth, this does not imply that further investments will increase growth even more (Puga 2002). Some of the more central regions of the EU arguably face constraints on future economic development, despite high levels of transport infrastructure endowment, because of the inability of the structure in place to cope with further economic growth (European Commission 1999). The nature of road infrastructure tends to mean that there are capacity limits, beyond which negative externalities (e.g. congestion costs) start to dominate. Productivity will decline as congestion exceeds a certain threshold level (Glaeser and Kohlhase 2004). Hence, congestion on urban roads may have a negative impact on productivity and thus lead to a negative growth rate. The existing transport infrastructure may become obsolete because of high spatial movements of the population and business activity or a change in technology (McCann and Shefer 2004). According to Puga (2002: 396), a better connection between two regions with different economic development levels not only gives firms in a remote region better access to the inputs and markets of more developed regions, but also makes it easier for firms in richer regions to supply poorer regions at a distance, and can thus harm the industrialisation prospects of less developed areas. Finally, a network of transport infrastructures may indirectly influence regional economic development either positively or negatively, through other public infrastructures such as the public buildings for education and hospitals. It should also be notes that regional spillovers can exist insofar as the network can generate positive or negative external effects beyond the regions where infrastructures are located.

There are many characteristics that distinguish road from rail infrastructure. First of all, a motorway is a light transport infrastructure, while railway is a heavy one. According to Puga (2002), the road infrastructure is likely to have a more substantial effect on the spatial allocation of production, and hence on regional inequalities. Lynde and Richmond (1992) have argued that public capital can play an important complementary role in the productivity of the regional private sector. The complementary role of road infrastructures 
in productivity is more significant than the role of rail infrastructure, because the services of the former are mostly freely distributed to private producers. The sunk infrastructure cost of railways (especially high-speed rail) is higher than the cost of roads. The value of the transportation infrastructure can vary significantly, not only among different forms of transport, but also from sector to sector and firm to firm (McCann and Shefer 2004). For example, high-speed rail lines are generally not suitable for the transportation of goods, and are thus unlikely to have much effect on the location of industry (Puga 2002).

But, how can we measure transport infrastructures? According to the European Commission (1999), the simplest measure of infrastructure is the physical scale of provision in relation to the potential use. Physical measures of the existing transport stock are used, as in Biehl's (1986) analysis. Road stock is usually measured as the length of road-motorways per square kilometre, while rail capital is measured as the length of railways per square kilometre. Nevertheless, the physical scale measurement does not give a clear picture of infrastructure stock, because it is extremely difficult to approach an estimation of the qualitative characteristics of the infrastructure capacity (Rovolis and Spence 2002). Questions related to infrastructure measurements remain open to analysis in greater depth (European Commission 1999; Haughwout 1998, 2002). ${ }^{2}$ Nevertheless, neither the indicators of scale nor of quality can convey how suitable the existing transport endowment in any region is to its regional development needs (European Commission 1999: 122).

The role of public transport infrastructure in regional development in Greece has not been systematically studied, however, there are several pieces of empirical research. The physical landscape of Greece, as argued later in this chapter, has some specific characteristics (mountainous areas, many islands, insularity, etc.) which have dictated the transportation networks in the country (Papadaskalopoulos and Christofakis 2008). Transport infrastructure in Greece has historically developed in several different phases. The most important period of public transport infrastructure construction was probably that of Trikoupis administration (1882-1892), in which $2600 \mathrm{~km}$ of roads, 65 bridges, and most importantly the great bulk of railway network (still in use) were constructed; in 1893, the

\footnotetext{
${ }^{2}$ Indicators of quality are tricky to define. For the rail network, the extent of electrification and the number of separate tracks, which affect both the speed of the service and its carrying capacity, can be used to give a reasonable indication of quality (European Commission 1999: 122).
} 
Corinth Canal was also completed (Christofakis 2007). The next important phase for investment in transport infrastructure was within the Venizelos administration during the first part of the twentieth century. Another phase in which important public works in transport were completed was during the fifties and sixties; actually, the main national highway that connects Athens and Thessaloniki, the backbone connecting Southern and Northern Greece was constructed during this period.

The most recent developments in public transport infrastructure are interwoven to EU cofunded transportation projects. These projects were financed through the various European Community Support Frameworks, the Cohesion Fund, etc. Papadaskalopoulos and Christofakis (2008: 166) have argued that during this phase, and especially since the midnineties, Greek regional development strategy has shifted its focus from scale - projects to strategic infrastructure projects, many of which were transport infrastructure investment. For instance, during the 1994-1999 planning period, begun the construction of major transport projects such as the motorway that connects Patra (in southwest Greece) to the Greek border to Turkey (northeast Greece), via Athens and Thessaloniki, the new Athens international airport 'Eleftherios Venizelos', the Rio-Antirio bridge (connecting Peloponnese to northern west Greece), the Aktio-Preveza tunnel, and a significant urban transportation project that of Athens Metro.

There are several studies analyzing specific transportation projects in Greece, but there are rather few studies investigating the transportation infrastructure impact on Greek regional development. Rovolis and Spence (2002) have examined infrastructure investment effect on the productivity of the private sector (on regional level); their overall finding is that public capital has a positive impact on regional private economy. Lambrinidis, Psycharis, and Rovolis (2005) examined the regional allocation of public infrastructure investment; their main findings is that the regional distribution of infrastructure investment was negatively associated with regional product per capita as well as with population size and population density, positively associated with the existing stock of infrastructure capital, and that infrastructure investment was linked to the political cycle (investment increased across prefectures in years preceding national elections). Rodríguez-Pose, Psycharis, and Tselios (2012) show that public investment in infrastructure in general and public investment in 
transport infrastructure in particular had a significant impact on regional growth in Greece, highlighting the primary importance of the spillover effects. Moreover, recent evidence highlights that public infrastructure investment, and more particularly transportation infrastructure, does have an effect on regional specialization in Greece, even though it is not clear the direction that this effect works (Tsekeris and Vogiatzoglou 2013). On one hand, better transportation infrastructure entails improved market access, which in turn leads to a reduction of specialization of manufacturing; on the other hand, enhanced transport infrastructure facilitates higher specialization of manufacturing.

\section{[Insert: Figure 3 and 4]}

Figures 3 and 4 show the rail and road network in Greece. There are some important observations. First, the comparative assessment of these figures reveals the disproportional higher priority that has been given to development the road network in Greece rather than the rail network. In addition the most advanced rail double tracked connection is that between Athens and Thessaloniki. Finally, the road network is much thicker and covers the entire territory of the country. However, the main corridors of the country are those connecting the large urban centres which serve as the main nodes of economic activity in the country (Thessaloniki, Larissa, Athens, Patra). As a result the transport infrastructure seems to serve but also to reinforce the existing development axes and nodes in the country.

\section{Do we need to look for additional drivers?}

The links between regional economic development, human capital and transport infrastructure are far less direct. This implies a need for the exploration of additional drivers. But, as there are a large number of drivers, we group them under two camps. The first camp places an emphasis on the physical geography of regions, known as the first nature of geography, while the second one stresses the geography of distance between economic agents known as the second nature of geography. Using the first nature of geography framework, we will analyse the role of natural endowments, and using the second nature of geography framework, we will discuss the role of urbanisation. It is not the aim of this section to review this vast array of sources, but simply to focus on their impact on regional economic development. 


\subsection{First nature of geography factors}

Adam Smith made a notable hypothesis that the physical geography of an area can influence its economic performance. Economic activity is geographically concentrated in particular areas with 'good' physical endowments, which induce factor inflows and thus increase income growth. The natural advantages of the regions are not uniformly distributed across all locations, causing regional disparities. Regions generally exploit their comparative advantage and the regional concentration of economic activities arises as regions produce and export products that are relatively intensive in the use of their abundant resource (Kim 1995). Hence, physical geography matters for the allocation of economic activities. Here, we will describe the role of climate, coastal proximity and the physical geography of coasts, and water and rivers.

A region's climate affects its economic development. First, disease ecology, agronomic processes and soil fertility can be influenced by climate and may, in turn, alter productivity (Mitchener and McLean 2003). For example, temperate climates favour productivity and economic development. Second, good weather is an amenity. For instance, cities with better weather than that of their countries in general have systematically higher rates of urban population growth (Cheshire and Magrini 2006). Third, changes in the occupational and wage structure are not independent of weather. For example, income inequality is higher in the Mediterranean countries which have many tourist resorts (e.g. the Greek islands) that offer part-time jobs, especially in the summer and for women and young people.

Coastal proximity and the physical geography of coasts crucially matter for economic development. Coastal regions enjoy a wider scope of the market than interior regions, which suffer from much higher transport costs. In China, for example, rapid growth and high efficiency take place in coastal cities, adding to the widening disparities of the interior. This shows that the socioeconomic benefits from city growth do not trickle down to rural areas (Naudé 2009). Another example is that landlocked African countries trade up to 92 per cent less with one another than with coastal countries, as they need to cross numerous borders (Coulibaly and Fontagne 2006). The proximity gap of landlocked African countries is further increased by neighbouring countries that are economically poorly performing, often as a 
result of conflict (Collier 2006). Therefore "[L]andlocked countries may be particularly disadvantaged by their lack of access to the sea, even when they are no farther than the interior parts of coastal countries, because cross-border migration of labor is more difficult than internal migration, infrastructure development across borders is much harder to arrange than similar investments within a country, and coastal countries may have military or economic incentives to impose costs on landlocked countries" (Gallup, Sachs, and Mellinger 1999: 184).

Water and rivers also matter for economic development. Access to navigable waterways directly affects productivity through transport costs, nutrition and population density. Africa has the lowest share of irrigated cropland in the developing world due to the relative scarcity of large rivers and alluvial plains (Sachs et al. 2004). Agriculture also depends more on access to fresh water than on access to the sea (Gallup, Sachs, and Mellinger 1999).

In Greece the physical landscape, shown in Figure 5, has, in one sense, dictated the spatial distribution of economic activity; this is apparent if Figure 1 (prefectural GDP per capita) is examined in conjunction with Figure 5, but also with Figure 6 which presents population density in the Greek prefectures.

[Insert: Figure 5]

Figure 5 presents the altitude, along with road network and main urban centres across Greece. It is obvious that the physical landscape in very diverse with mountainous, plains and islands. Two observations come out from this picture. First, the main urban centres of the mainland are at the coastal areas and located in the eastern part of the country. Comparing this Figure with the previous Figures 1, 2, 3 and 4 it is obvious that the there is a coincidence between natural geography, concentration of people and production activity, transport infrastructures and level of economic development.

\subsection{Second nature of geography factors}

Economic theory has ambiguous predictions about the likely effects of urbanisation through efficiency gains from low distance between economic agents. Here, urbanisation relates to features that depend on the spatial interaction between people and/or between firms in an 
area, but are not necessarily inherited (Naudé 2009). The role played by urbanisation in economic development and growth has been emphasised by urban economists, development economists, growth economists and economic historians, among others. The main conclusion is, without a doubt, that economic development and urbanisation are mutually self-reinforcing processes.

Urbanisation in one region is likely to spur economic development and growth because it reduces the costs of innovation, infrastructure, information and transactions in that region through technological and pecuniary externalities. ${ }^{3}$ This trend is evinced most especially in the writings of the new growth and new economic geography theorists. Improvements in transport and communications processes tend to reinforce the clustering of economic activity by widening the market range of any given centre and by helping to spark off new rounds of specialisation in established urban areas (Scott and Storper 2003: 582). Cities allow goods, ideas and people to come together for the purposes of exchange and production (Polese 2005). This allows regions to reap the gains of trade and specialisation, increasing economic development and efficiency. Cities foster and facilitate flows of local knowledge, ideas and innovations, the creation of dense socioeconomic networks and the production of behavioural and cultural change. In cities, people have face-to-face contact, which is a fundamental prerequisite of tacit knowledge spillovers. Interaction between people promotes innovation, continually pushing up productivity, growth and efficiency (Jacobs 1970). Although the advent of new information and communication technologies has enormously increased the quantity, complexity and variety of the information and knowledge generated, face-to-face contact complements rather than substitutes for each other form of contact, such as an e-mail contact (McCann and Shefer 2005).

Urbanisation is likely to spur economic development and growth when its economic benefits outweigh its costs. On the one hand, the economic benefits of urbanisation arise due to the presence of knowledge spillovers among firms in an industry, a build-up of knowledge and ideas associated with historical diversity, the local competition of an industry, and the lower infrastructure, information, transaction, training and recruitment costs (Polese 2005).

\footnotetext{
${ }^{3}$ The former 'deal with the effects of nonmarket interactions that are realised through processes directly affecting the utility of an individual', while the latter 'are by-products of market interactions' and 'arise from imperfect competition' (Fujita and Thisse 2002: 8).
} 
People may move to cities for reasons unrelated to their economic performance, for example, for the schools. On the other hand, the costs of urbanisation rise due to the commuting expenditures within cities, the substantial pollution and the pervasive traffic congestion (Bertinelli and Black 2004). The economic costs also rise from the pressure posed by geographic concentration on urban factor markets that bids up prices and from dispersed demand (Martin and Ottaviano 2001). Therefore, cities act as locations where technological, economic and social innovations are developed (Bräuninger and Niebuhr 2005), enhancing the economic chances and opportunities of working people.

Nevertheless, reverse causation in the positive development-urbanisation relationship is a subject of debate. Economic development is likely to foster agglomeration, because as the sector at the origin of innovation expands, new firms tend to locate close to that sector (Martin and Ottaviano 2001). The gains for a particular firm from being located in an urban area are scale economies due to greater market size, flexible and rapid input relationships and the presence of a large and diversified labour pool. The agglomeration of talented and educated individuals in specific areas encourages firms (e.g. research centres) to locate to those areas, and vice versa. According to the new economic geography context, the positive relationship indicates that the centripetal forces (knowledge spillovers and increasing returns to scale) are strong enough to offset the centrifugal forces (congestion and transportation costs).

The city size matters for the relationship between urbanisation and development. Large cities depend more on 'urbanisation' economies, while small cities depend more on 'localisation' economies (McCann and Shefer 2004). They are locomotives of the national economies within which they are situated, in that they are the sites of dense masses of interrelated economic activities (Scott and Storper 2003). They also offer a wider selection and better quality of the producer services that are essential to technological innovation than the smaller ones. The level of urbanisation differs across space because only a few regions are able to attract investments in innovation and to acquire production capacity (Scott and Storper 2003). Uneven densities of agglomerations can influence the overall rates of regional economic development through locational interdependencies. 
To sum up, conventional theories on the relationship between urbanisation and regional economic development and growth have favoured the view that a circular causation between growth and a concentration of economic activities sets in. However, the causal link between these two processes is not clear cut.

[Insert: Figure 6]

Figure 6 portraits the NUTS III regions in Greece according to the population size. Regions of Attiki (hosting the capital city of Athens) and Thessaloniki (hosting the city of Thessaloniki) which rank first and second in the population density are also regions with relatively higher level of economic development. Furthermore, the most densely populated areas of the country are located across the eastern costal area of the country as it happens with the distribution of economic development. As a result, the map of population density resembles the development map of the country. Therefore, population density and level of economic development seems be correlated significantly across space. However, the direction of causality between density and development is far from conclusive. Finally, The Greek islands with lower population density show high levels of economic development. This is most probably due to the fact that in this case the first-nature geography impacts on the level of economic prosperity.

It should be mentioned here that the first and the second nature of geography can be complementary. First nature helps to explain initial differences in outcomes across regions, while second nature helps to account for ways in which those initial differences are magnified through positive and negative feedback (Puga 2002). A city might, for example, originally emerge because of cost advantages arising from differentiated geography, but then continue to thrive as a result of agglomeration economies even when the cost advantages have disappeared (Gallup, Sachs, and Mellinger 1999: 184). In other words, first nature geography may give a region an initial advantage, which then becomes amplified by second nature agglomeration forces. Second nature of geography is important in explaining why areas with similar first nature of geography may end up at different levels of productivity and income (Naudé 2009). 


\section{Regional economic policy: equity and efficiency}

The analysis of the relationship between regional economic development, human capital and transport infrastructures provides useful insights that may be vital in the planning of regional policy. Generally speaking, regional policy should seek a synergy in the achievement of both efficiency and equity. However, this may involve trade-offs in the extent to which the two goals can be attained. The pursuit of these goals is a matter of political choice (Wossmann and Schütz 2006).

The goals of European and Greek educational policy are two-fold, encompassing both goals of efficient allocation and goals of equitable distribution. The goals of efficiency and equity are likely to be achieved at each level of formal education and are not trade-offs, since educational policies may advance both efficiency and equity in such a way that each complements the other. The concept of equity is more elusive because it has to do with scientific definitions of fairness and justice (Wossmann and Schütz 2006). Inequality in educational attainment should be tolerated only if it is due to differences in individual levels of effort (e.g. studying), but not if it is due to circumstances which are beyond a person's control (e.g. family background). Hence, a person's expected educational outcome should be a function only of his/her effort, but not of his/her circumstances (Wossmann and Schütz 2006). If this is the case, then individual abilities, along with certain specific traits and qualities, are likely to play the most prominent role in the income-education relationship. The existing studies (Rodríguez-Pose and Tselios 2009; Tselios 2008) highlight the fact that educational policies have an impact on welfare policies. The pursuit of the goal of equitable educational distribution is likely to decrease inequality in productivity and, thus, in income. Policy-makers can also address equity and/or efficiency through public investments. However, policy-makers should take into account the fact that externalities spill over the barriers of regional economies. Welfare and educational policies should account for the spillover effects with adjoining regions. Trade, migration, infrastructure and technological policies may also lead to geographically dependent regions. Factors such as labour force mobility, capital mobility, technology and transportation costs may be particularly important, because they directly affect regional interactions (Le Gallo, Ertur, and Baumont 2003). Income inequality can affect growth through investment in physical and human capital. 
Classical economists support the notion that more income inequality favours physical capital accumulation, because the rich agents have a higher marginal propensity to save compared to the poor. This increases aggregate savings, which in turn increases growth rates. Contrary to the classical approach, the modern one (Galor 2000) suggests that the relationship between income inequality and growth depends on the stage of economic development.

The relationship between income inequality within a nation and economic growth can also be investigated through political economy models (Perotti 1992). The basic argument for the negative effect of inequality on growth is that the higher the income inequality, the higher the rate of taxation, the lower the incentive to invest and the lower the growth rate (Bertola 1993). The argument in support of a positive effect, on the other hand, is that the higher the income inequality, the higher the rate of taxation, the larger the expenditure on public education programmes, and thus the higher the public investment in human capital and the higher the growth rate (Aghion and Bolton 1990). Hence, the trade-off between the incentive to invest (which is the fundamental mechanism of a laissez-faire economy) and the expenditure on public education programmes (which reflects a fundamental government policy of a command economy) determines the inequality-growth relationship. Finally, the effect of income inequality within a nation on economic growth also depends upon the effect of socio-political instability (Alesina and Perotti 1996). However, this channel plays a key role in the inequality-growth relationship of less-developed countries beset by political and social unrest or violence.

The empirical research that has been carried out on the effect of income inequality on economic growth is less unambiguous than the theory. Some studies find that inequality has a negative effect on growth (e.g. Barro 2000), while others find a positive effect (e.g. Forbes 2000). At a regional level, Rodríguez-Pose and Tselios (2010) have shown that the low interpersonal income and educational inequalities in Europe are likely to increase growth, but the size of their impact is small. European policy-makers, therefore, should take into account the fact that inequality is strongly related to growth, but the scale of the effect is relatively small, and thus the effectiveness of a regional policy to increase growth through inequalities is likely to be low. Educational inequality motivates and enables people to increase their investment in human capital in order to obtain higher educational 
qualifications, because they require qualifications that are not possessed by everyone so as to benefit from the higher returns on their skills. Income inequality enables people to acquire well-paid jobs, increasing competition in the labour market and, therefore, growth and efficiency. Public policies (e.g. tax policies) aimed at reducing income inequality may not be strong enough to produce negative incentives. The positive inequality-growth relationship highlights the fact that regional policies involve a trade-off, by either advancing growth efficiency to the detriment of educational and income equity or by advancing equity to the detriment of efficiency.

To sum up, the analysis shows the significance of a combined regional policy perspective that would address other policies such as labour market policies, educational policies, social policies, institutional policies and immigration policies. The combined policy should determine joined-up policy solutions, which encompass both the goal of economic efficiency and the goals of equitable income and educational distribution. The extent to which each of these goals should be pursued is a matter of political choice.

\section{Some concluding remarks}

The complex relationship between regional development, human capital and transport infrastructure has puzzled economists, economic geographers, and social scientists in general for long. The standard measure of regional economic development is GDP per capita. However, there are many conceptional problems with this. Even the definition of the spatial analysis unit, the region, is not always unproblematic; in the Greek context, for instance, the capital city, Athens, is much smaller than its Functional Urban Region.

Two of the major 'forces' that determine regional economic development is human capital (i.e. educational attainment) and transport infrastructure (i.e. road and rail infrastructure). There are however and some other factors that shape and moderate regional economic development. As we have argued here, physical geography, a first nature geographical factor (in New Economic Geography parlance), and urbanization, a second nature geography factor, have influenced the economic development of Greek regions. The analysis of all these drivers of regional economic development should inform both national and European 
policies that affect directly, (for instance transport networks), or indirectly, (for instance, education policy), the fate of the regions. 


\section{References}

Aghion, P. and P. Bolton. 1990. Government domestic debt and the risk of default: a political economic model of the strategic role of debt. In Public debt management: theory and history, ed. R. Dornbusch and M. Draghi, Chapter 11. Cambridge: Cambridge University Press.

Alesina, A. and R. Perotti. 1996. Income distribution, political instability, and investment. European Economic Review 40:1203-1228.

Allen, J. and R. van der Velden. 2001. Educational Mismatches Versus Skill Mismatches: Effects on Wages, Job Satisfaction, and On-the-job Search. Oxford Economic Papers-New Series 53:434452.

Armstrong, H.W. and J. Taylor. 2000. Regional economics and policy. Oxford: Blackwells.

Aschauer, D.A. 1989. Is public expenditure productive. Journal of Monetary Economics 23:177-200.

Barro, R.J. 2000. Inequality and growth in a panel of countries. Journal of Economic Growth 5:5-32.

Becker, G.S. 1962. Investment in human capital - a theoretical analysis. Journal of Political Economy 70:9-49.

Becker, G.S. and R.J. Barro. 1988. A Reformulation of the Economic Theory of Fertility. Quarterly Journal of Economics 103:1-25.

Becker, G.S. and N. Tomes. 1986. Human capital and the rise and fall of families. Journal of Labor Economics 4:S1-S39.

Benporath, Y. 1980. The F-Connection - Families, Friends, and Firms and the Organization of Exchange. Population and Development Review 6:1-30.

Bertinelli, L. and D. Black. 2004. Urbanization and growth. Journal of Urban Economics 56:80-96.

Bertola, G. 1993. Factor shares and savings in endogenous growth. American Economic Review 83:1184-1198.

Biehl, D. 1986. The Contribution of Infrastructure to Regional Development. Luxembourg: Final Report of the Infrastructure Studies Group to the Commission of the European Communities, Office for Official Publications of the European Communities.

Bourdieu, P. 1993. Sociology in Question. London: Sage.

Bräuninger, M. and A. Niebuhr. 2005. Convergence, Spatial Interaction and Agglomeration Effects in the EU: HWWA Discussion Paper 322, Hamburg Institute of International Economics.

Centre for Educational Research and Innovation and Organisation for Economic Co-operation and Development. 1998. Human capital investment: an international comparison. Paris: Organisation for Economic Co-operation and Development.

Cheshire, P.C. and D. Hay. 1988. Urban Problems in Western Europe: an Economic Analysis. London: Unwin Hyman.

Cheshire, P.C. and S. Magrini. 2006. Population Growth in European Cities: Weather Matters - But Only Nationally. Regional Studies 40:23-37.

Christofakis, M. 2007. Transports and Regional Development: The Transport Infrastructures Policy (in Greek). Athens: Dionikos.

Coleman, J.S. 1988. Social Capital in the Creation of Human Capital. American Journal of Sociology 94:S95-S120.

Collier, P. 2006. African growth: why a 'big push'? Journal of African Economies 15:188-211.

Coulibaly, S. and L. Fontagne. 2006. South-South trade: geography matters. Journal of African Economies 15:313-341.

De Serres, A. 2003. Structural Policies and Growth: a Non-Technical Overview: OECD Economics Working Paper No. 355, Organization for Economic Co-Operation and Development (OECD) Economics Department (ECO).

Deichmann, U.; M. Fay; J. Koo; and S.V. Lall. 2004. Economic structure, productivity, and infrastructure quality in Southern Mexico. Annals of Regional Science 38:361-385.

Demurger, S. 2001. Infrastructure Development and Economic Growth: an Explanation for Regional Disparities in China? Journal of Comparative Economics 29:95-117. 
Duffydeno, K.T. and R.W. Eberts. 1991. Public Infrastructure and Regional Economic Development - a Simultaneous Equations Approach. Journal of Urban Economics 30:329-343.

European Commission. 1999. The European regions: sixth periodic report on the socio-economic situation in the regions of the European Union. Luxembourg: Official Publication Office.

- - - 2004. A New Partnership for Cohesion: Convergence, Competitiveness, Cooporation. Luxembourg: Third report on economic and social cohesion; Office for Official Publications of the European Communities.

Forbes, K.J. 2000. A reassessment of the relationship between inequality and growth. American Economic Review 90:869-887.

Fujita, M. and J.-F. Thisse. 2002. Economics of Agglomeration: Cities, Industrial Location, and Regional Growth. Cambridge: Cambridge University Press.

Gallup, J.L.; J.D. Sachs; and A.D. Mellinger. 1999. Geography and economic development. International Regional Science Review 22:179-232.

Galor, O. 2000. Income distribution and the process of development. European Economic Review 44:706-712.

Glaeser, E.L. and J.E. Kohlhase. 2004. Cities, Regions and the Decline of Transport Costs. Papers in Regional Science 83:197-228.

Greene, K.V.; W.B. Neenan; and C.D. Scott. 1974. Fiscal Interactions in a Metropolitan Area.

Hanushek, E.A. and D.D. Kimko. 2000. Schooling, labor-force quality, and the growth of nations. American Economic Review 90:1184-1208.

Hartog, J. 2000. Over-Education and Earnings: Where Are We, Where Should We Go? Economics of Education Review 19:131-147.

Haughwout, A.F. 1998. Aggregate production functions, interregional equilibrium, and the measurement of infrastructure productivity. Journal of Urban Economics 44:216-227.

- - . 2002. Public Infrastructure Investments, Productivity and Welfare in Fixed Geographic Areas. Journal of Public Economics 83:405-428.

Henderson, J.V.; Z. Shalizi; and A.J. Venables. 2001. Geography and Development. Journal of Economic Geography 1:81-105.

Holtz-Eakin, D. 1994. Public-sector capital and the productivity puzzle. Review of Economics and Statistics 76:12-21.

Holtz-Eakin, D. and M.E. Lovely. 1996. Scale economies, returns to variety, and the productivity of public infrastructure. Regional Science and Urban Economics 26:105-123.

Jacobs, J. 1970. The economy of cities. London: Cape.

Kim, S. 1995. Expansion of Markets and the Geographic Distribution of Economic Activities - the Trends in Us Regional Manufacturing Structure, 1860-1987. Quarterly Journal of Economics 110:881-908.

Lambrinidis, M.; Y. Psycharis; and A. Rovolis. 2005. Regional allocation of public infrastructure investment: the case of Greece. Regional Studies 39:1231-1244.

Le Gallo, J.; C. Ertur; and C. Baumont. 2003. A spatial econometric analysis of convergence across European regions, 1980-1995. In European regional growth, ed. B. Fingleton. Berlin: Springer.

Lynde, C. and J. Richmond. 1992. The Role of Public Capital in Production. Review of Economics and Statistics 74:37-44.

Martin, P. and G.I.P. Ottaviano. 2001. Growth and agglomeration. International Economic Review 42:947-968.

McCann, P. and S. Shefer. 2004. Location, agglomeration and infrastructure. Papers in Regional Science 83:177-196.

- - . 2005. Agglomeration, Economic Geography and Regional Growth. Papers in Regional Science 84:301-309.

Mitchener, K.J. and I.W. McLean. 2003. The Productivity of US States Since 1880. Journal of Economic Growth 8:73-114. 
Naudé, W. 2009. Geography, transport and Africa's proximity gap. Journal of Transport Geography 17:1-9.

OECD. 2003. Seizing the Benefits from ICT - an International Comparison of the Impacts of ICT on Economic Performance: Centre for Educational Research and Innovation, Paris, forthcoming.

Papadaskalopoulos, A. and M. Christofakis. 2008. Transport and Regional Development: The Pattern of Spatial Development in Greece Due to the Impact of the New Transportation Corridors. In Regional Analysis and Policy: The Greek Experience, ed. H. Coccossis and Y. Psycharis. Heidelberg: Physica-Verlag.

Perotti, R. 1992. Income distribution, politics, and growth. American Economic Review 82:311-316.

Petrakos, G. and Y. Psycharis. 2015a. Regional Development in Greece (in Greek). Athens Kritiki.

- - . 2015b. The spatial aspects of economic crisis in Greece. Cambridge Journal of Regions, Economy and Society.

Polese, M. 2005. Cities and national economic growth: a reappraisal. Urban Studies 42:1429-1451.

Puga, D. 2002. European regional policies in light of recent location theories. Journal of Economic Geography 2:373-406.

Putnam, R.D. 1993. The Prosperous Community: Social Capital and Public Life. The American Prospect 13:35-42.

Rodríguez-Pose, A.; Y. Psycharis; and V. Tselios. 2012. Public investment and regional growth and convergence: Evidence from Greece. Papers in Regional Science 91:543-568.

Rodríguez-Pose, A. and V. Tselios. 2009. Education and income inequality in the regions of the European Union. Journal of Regional Science 49:411-437.

- - . 2010. Inequalities in income and education and regional economic growth in western Europe The Annals of Regional Science 44:349-375.

Rovolis, A. and N. Spence. 2002. Promoting regional economic growth in Greece by investing in public infrastructure. Environment and Planning C-Government and Policy 20:393-419.

Sachs, J.D.; J.W. McArthur; G. Schmidt-Traub; M. Kruk; C. Bahadur; M. Faye; and G. McCord. 2004. Ending Africa's poverty trap. Brookings Papers on Economic Activity:117-240.

Schuller, T. 2000. The Complementary Roles of Human and Social Capital. In International Symposium on the Contribution of Human and Social Capital to Sustained Economic Growth and Well-Being. Quebec City, Canada.

Schultz, T.W. 1961. Investment in human capital. American Economic Review 51:1-17.

-- . 1962. Reflections on investment in man. Journal of Political Economy 70:1-8.

- - . 1963. The Economic Value of Education. New York: Columbia University Press.

Scott, A.J. and M. Storper. 2003. Regions, Globalization, Development. Regional Studies 37:579-593.

Sianesi, B. and J. Van Reenen. 2003. The returns to education: macroeconomics. Journal of Economic Surveys 17:157-200.

Spence, A.M. 1973. Job market signaling. Quarterly Journal of Economics 87:355-374.

Stimson, R.J.; R.R. Stough; and B.H. Roberts. 2006. Regional economic development: Analysis and planning strategy Springer.

Tsekeris, T. and K. Vogiatzoglou. 2013. Regional specialization and public infrastructure investments: Empirical evidence from Greece: Centre of Planning and Economic Research, Discussion Papers, No. 130.

Tselios, V. 2008. Income and educational inequalities in the regions of the European Union: geographical spillovers under welfare state restrictions. Papers in Regional Science 87:403430.

Vickerman, R.W. 1991. Infrastructure and regional development. London: Pion.

Wang, E.C. 2002. Public infrastructure and economic growth: a new approach applied to East Asian economies. Journal of Policy Modeling 24:411-435.

Wossmann, L. and G. Schütz. 2006. Efficiency and Equity in the European Education and Training Systems: Analytical Report for the European Commission, prepared by the European Expert Network on Economics of Education, Mimeo. 